\title{
The Monetary Reforms of the Romans and the Finds of Roman Denarii in Eastern and Northern Europe
}

\section{Lennart Lind}

\begin{abstract}
Monetary measures undertaken inside the Roman Empire might be responsible for the composition of finds of Roman coins made outside the Empire. A possible link between the composition of the denarius finds in Barbarian Europe, on the one hand, and the monetary reforms of Nero (54-68) and Septimius Severus (193-211), on the other hand, has long been recognized. There is however a third Roman monetary reform which has put its imprint on the denarius finds in Central, Eastern and Northern Europe, the one of Domitian (8l-96).
\end{abstract}

Lennart Lind, Department of Classical Archaeology and Ancient History. Stockholm University, S-10691 Stockholm, Sweden.

About 7,500 Roman denarii, almost all from the period 64-200, are known from finds in Sweden (1990). The coins were unearthed mainly on Gotland, which alone accounts for c. 6,500 of the c. 7,500 denarii from Sweden. Only c. 1,000 denarii come from other parts of the country, i.e. Öland and the mainland (especially Halland and Skåne). As for the rest of Scandinavia, Denmark has c. 2,000 denarii and Norway and Finland almost none (Lind forthcoming).

In Europe outside the limits of what was once the Imperium Romanum, Scandinavia excepted, Roman denarii have been found in the northern parts of the Netherlands, in Germany (FRG and the former GDR), Poland, Czechoslovakia, the former Soviet Union and the "non-Roman" parts of Hungary and Rumania; Poland and the former Soviet Union enjoy the richest supplies. The Danish and the European continental material in its entirety show approximately the same composition as that of Sweden, i.e. the decisive weight in most countries rests on coins struck during the period 64-200, from the reign of Nero (54-68) to that of Septimius Severus (193-211). All the considered countries have coins from the period before the year 64 . As for their number, however, they cannot compete with later coins, and they are usually found separately and form problems of their own (Lind forthcoming).

Most of the denarii found on Gotland are preserved and available for study; their extreme degree of wear is believed to prove that the coins changed hands repeatedly in antiquity. The denarii from the other parts of Sweden, as well as those from Denmark, are as a rule less worn than those from Gotland. The denarii from the rest of continental Europe, outside the limes, are sometimes very worn, sometimes in a rather good state of preservation. The denarii known to have been found in Denmark are extant to a large degree; of the coins known to have been unearthed in other parts of the Continent, however, only a minor part is available for study.

It has been known for a very long time that monetary measures undertaken inside the Roman Empire, for purely internal reasons, in some way might be responsible for the composition of finds of Roman coins made outside the frontiers of the Empire. Already in 1860 Theodor Mommsen pointed to a possible link between the composition of the denarius finds in Europe outside the limes on the one hand, 
and the monetary reform of Nero in the $60 \mathrm{~s}$ (which reduced the weight and the fineness of the silver coins) and the great debasement of the denarius under Septimius Severus in the 190s (which diminished the intrinsic value of a coin with one-third) on the other (Mommsen 1860:771-774). The relevance of these findings of Mommsen for the material in Sweden, especially that on Gotland, was shown already in 1866 by Hans Hildebrand (1866:60f). There is, however, a third Roman monetary reform which has put its imprint on the denar$i u s$ finds in central, eastern and northern Europe. I will come back to this presently.

The written sources from antiquity do not have any information (at least not any we can understand) answering the question of when and from where the Roman denarii found their way into the area of what today is Sweden. As to the general direction of the flow of the coins from the Imperium Romanum to present-day Sweden, Gotland included, I think it is possible to establish it by comparing the finds in Sweden with those from the areas between the former Roman Empire and Sweden of today. I will start with a survey of the general situation in Sweden; after that I will deal with the more important finds in some detail, and then compare them to some finds on the European continent. For reasons that will become obvious, special attention will be given to the early coins of the hoards. For the sake of convenience I will shorten the argument by using only the largest, well-described, continental European hoards.

Finds of 1 or 2 denarii are not very common in Sweden; most coins belong to hoards of varying sizes, some consisting of hundreds of coins. The character of the Swedish material is such that even if coins of the period prior to Nero are almost totally absent, and coins of the period after Septimius Severus are very rare, all emperors within the more coin-concentrated span 64-200 are nevertheless represented; and what holds for the material as a whole also holds, by and large, for individual finds, on Gotland as well as the Swedish mainland. The most important finds on Gotland are distinguished by the fact that they are endowed with a preponderance of denarii from the period of the three Antonine rulers (138-192) - Antoninus Pius, Marcus Aurelius and Commodus - and that the period with the second largest store of coins is the one of Trajan and Hadrian (98-138), i.e. the two preceding emperors. The denarii from the period of Nero to Nerva (54-98), and those from the period of Pertinax to Septimius Severus (193-211), are almost always (cf. below) very few in number, but they are seldom totally absent; the earlier group is commonly larger than the latter (cf. below). Most of the larger finds on Gotland also contain one or a few specimens of so-called barbarian imitations.

Let us now examine the more important finds in some detail. On Gotland there are eight hoards exceeding 200 coins each, i.e. Lind 1981 nos. 8, 18, 43, 44, 53, 62, 63 and 89 , and one with somewhat less than 200 coins, no. 9 (181 coins). Together these nine hoards make up about two-thirds of the c. 6,500 denarii unearthed on Gotland. (One important find on Gotland, Lind 1981 no. 73, has been disregarded here.) In the rest of the country there are only two hoards of corresponding size, both from the southern part of the mainland, Lind 1981 no. 186 (Skăne), and no. 190 (Halland), respectively, together comprising more than $80 \%$ of the denarii found in Sweden outside Gotland.

Table 1 shows the contents of these eleven hoards (Lind 1981 nos. 8, 18, 44 and 62 with additions from Lind forthcoming) distributed in per cent based on emperors' reigns, the periods before 98 and after 192 forming but one group each, Nero-Nerva and Pertinax(Septimius) Severus respectively. As for genuine Roman coins, these hoards all consist of denarii from the period 64-200, with the exception of a drachma of Lycia with the portrait of Trajan in no. 62 (it is the only one of its kind found in Sweden and the only Greek Imperial silver coin found in Scandinavia). As is clear from Table / all, with the exception of no. 190 (Halland), mainly consist of coins from the five emperors Trajan (98-117), Hadrian (117- 
138), Antoninus Pius (138-161), Marcus Aurelius (161-180) and Commodus (180-192), but with the exception of no. 44 (Gotland) they all also have coins from before 98 as well as after 192; the latter group is missing in no. 44.

Eight of the nine hoards from Gotland show a clear resemblance to one another. The biggest portion in each of them, roughly onethird (29.2-34.4\%) falls to Antoninus Pius' reign; and next in line comes Marcus Aurelius, with one-fourth in each hoard (22.1-28.0 $\%)$; then in seven out of eight cases Hadrian, with between 15.6 and $21.0 \%$ (in the remaining case, no. 89 , Hadrian has only about 10 $\%)$. After this it is normally Trajan and Commodus which end up in fourth and fifth position, with roughly one-tenth each $(6.1-13.4$ and $10.4-14.9 \%$ respectively). The coins of the periods before Trajan and after Commodus - as well as the barbarian imitations, which are present in all of these eight hoards - constitute everywhere small groups, which in terms of volume cannot compete with any of the five belonging to the five emperors from the period 98-192. The ninth hoard, the aberrant no. 44 , where the coins of Hadrian and Trajan form the largest groups and with more coins of the period Nero-Nerva than from that of Commodus, only serves to emphasize the homogeneity of the others.

None of the hoards from the mainland conform closely to the pattern of the eight hoards on Gotland. The largest one, no. 186 (Skåne), shows a preponderance of coins from the Antonines (138-192), stronger than that in any of the Gotlandic hoards shown here. And in no. 190 (Halland) the pre-98 coins form a more significant portion than in any other find, about one-third of the total, and none of the emperors of the second century has more than $18 \%$. Like no. 44 on Gotland, nos. 186 and 190 emphasize the homogeneity of the eight Gotlandic finds.

Where outside Sweden do we encounter hoards with a composition similar to the larger ones on Gotland? As for the large Continental hoards, it turns out, and this is very interesting, that just about all hoards of 1,000 or more reasonably well-described specimens listed in my catalogue (nine in all) are made up essentially of coins from the period of the Antonines (138-192), with the exception of one find from Czechoslovakia (Lind 1981 no. 394) and one from Rumanian Moldavia (Lind 1981 no. 403; concerning finds in Rumanian Moldavia, see Mihailescu-Birliba 1980). Also worthy of notice is the pattern of geographical distribution: five of these finds of 1,000 coins or more, all with a composition rather similar to that of the larger finds on Gotland (cf. below), have been discovered at geographical localities - in present-day Hungary and Poland - which follow, or are oriented along, a roughly straight south-north line - a line going from the Hungarian plain to Gotland.

The contents of four of these five large Continental hoards, Lind 1981 nos. 279, 295 and 296 (Mitkowa-Szubert 1989) from Poland and no. 398 (Biro-Sey 1987) from Hungary, are so well known that it is possible to compare them in detail with those of the more important finds on Gotland. Table 2 is arranged in the same way as Table $I$ and shows the percentage composition of these four hoards, as well as that of the nine Gotlandic hoards, which are here shown in two columns only, the two largest hoards, nos. 18 and 62, being presented as one hoard; nos. 8, 9, 43, 44, 53, 63 and 89 have also been combined into one. The four Continental hoards all essentially consist of denarii from the Nero-Septimius Severus period, as do those from Sweden/ Gotland, but some of them have a few earlier and/or a few later coins, i.e. of the Republic (before $30 \mathrm{BC}$ ) or Marcus Antonius (32-31 $\mathrm{BC}$ ) on one hand, and of Caracalla (211-217) or Macrinus (217-218) on the other. As on Gotland, there are no coins of Nero issued before his monetary reform in AD 64.

Here, too, the coins of Antoninus Pius constitute about one-third of each hoard (32.2$34.7 \%$ ), Marcus Aurelius comes as number two, with about one-fourth (24.9-28.0\%), and in the third place we have Hadrian (13.5$16.1 \%)$; Commodus has roughly one-tenth 
(8.9-2.1\%), and Trajan somewhat less $(6.2-$ $9.4 \%)$. The most important difference between the Continental hoards and the Gotlandic ones is that the pre-98 coins in some of the former, i.e. in nos. 295-296, are a distinctly larger group than in any of the latter.

In the nine Gotlandic hoards, as well as in three of the four continental European hoards (the exception is no. 398 from Hungary), the pre-98 coins form a distinctly larger group than those from the period after 192 (and the barbarian imitations, which are lacking in nos. 295-296). As mentioned, I think that the earliest coins of the hoards, i.e. those of the 64-98 period, are of special interest, and they will be treated in some detail. Before we go on with this, however, we must say something about the post-192 coins, and about finds from the territory of the former Roman Empire with a series of pre- 200 coins similar in structure to that of the above-discussed hoards outside the limes.

The post-192 coins are shown in Table 3, with column-headings as in Table 2 . The coins are distributed according to emperors' reigns, but the reign of Septimius Severus (193-211) has been divided into two groups, "Septimius Severus 1" and "Septimius Severus 2", respectively. The first group comprises coins with the portrait of Septimius Severus issued before his great debasement of the denarius in late 194 or early 195, and coins with the portrait of his wife Julia Domna struck 193196 (Septimius Severus RIC 1-39; Julia Domna RIC 534-538), presumably belonging to the same period. The second group comprises the other coins from Severus' reign.

One observes that the short-lived emperors Pertinax and Didius Julianus (spring 193), as well as Clodius Albinus (193-197), are represented everywhere, except in no. 398, where the post-192 coins exclusively belong to the first Severan dynasty (193-217).

In the Gotlandic finds as well as in the Continental finds nos. 279, 295 and 296 the coins of Severus are essentially from the time before his great debasement of the denarius ("Septimius Severus 1"); in these hoards coins struck after that debasement seem to have been avoided. The conclusion can be drawn that when these Gotlandic and continental European hoards were amassed, the debasement of 194/195 was taken into consideration (except perhaps in the case of no. 398), though this reduction of the coin's intrinsic value certainly was not officially advertised (it is not mentioned in the literary sources) or meant to be easily discovered (cf. Kellner \& Specht 1961:49). Thus the Gotlandic hoards as well as the continental European ones must have been formed at a time when, and in a place where, the debasement of Severus and its implications had become well known.

As I have argued elsewhere (Lind 1988:200203), the most likely place for the accumulation of these hoards found in Barbarian Europe is, in fact, the Roman Empire, and the most likely point in time AD 220 or later. The plausibility of this hypothesis is corroborated by Table 4, which compares the contents (distributed in percentages based on emperors' reigns) of two of the hoards found outside the limes, the by now well-known Lind 1981 no. 62 from Gotland and no. 279 from Poland, with the pre-debasement contents of four hoards found inside the former Roman Empire and deposited after 220. These hoards are the huge Reka-Devnia find (Mouchmov 1934) from Bulgaria, the find of Viuz-Faverges (Pflaum \& Huvelin 1981) in France, that of Cologne (FMRD 6 no. 1004,3) and of Kempten (FMRD I no. 7186) in the southern parts of the FRG. The only coins after 192 included are those of Pertinax, Didius Julianus and Clodius Albinus, as well as Septimius Severus RIC 1-39 and Julia Domna RIC 534-538.

The pre-debasement contents of these four hoards, as shown by Table 4, have a preponderance of coins of Hadrian, Antoninus Pius and Marcus Aurelius (117-180), and a distinct presence of coins of Trajan (98-117) and Commodus (180-192). These hoards clearly demonstrate that denarii from the period before the great debasement of Severus (194/ 195) were at hand in the $220 \mathrm{~s}$ and later within the borders of the Roman Empire, and that 
they had a general chronological distribution compatible with that of the denarii of the hoards of the Barbarian world, which are discussed here and which, as we have seen, almost exclusively consist of pre-debasement coins. It is thus possible to argue, as I have done, that the denarii of these hoards might have been exported en bloc in the third century, but the case is not yet fully proven.

Let us now turn to the earliest coins. $\mathrm{Ta}$ bles $5 a-5 c$ show the percentage distribution based on emperors' reigns of the 64-98 period coins of all previously mentioned hoards. As we can see from Table $5 a$, with the eleven Swedish finds, and Table $5 b$, with the Gotlandic and the Continental finds arranged in columns as in Table 2 above, the most frequent coins among those from the 64-98 period are those of Vespasian's 10-year reign (69-79). By comparison, Domitian's 15-year reign (81$96)$ is normally underrepresented, though one exception is no. 89, Gotland; no. 190 from the mainland, on the other hand, with the largest number of pre-98 coins in any Swedish find (cf. above), conforms to the pattern, see Table $5 a$. As shown by Table $5 c$, with the four finds from the Empire in Table 4 above, the relationship is the same in third-century hoards from the Roman Empire. In several finds the coins of Titus' short reign (79-81), and/or that of Nerva (96-98), are more numerous than those issued under Domitian's authority, see no. 62 in Table $5 a$, no. 398 in Table $5 b$ and Reka-Devnia and Kempten in Table $5 c$.

The rareness in hoards of coins of Domitian's reign, as compared to those of Vespasian's, was observed early in the twentieth century (Regling 1912:232f; Bolin 1926:119f), but not until recently has it been proven satisfactorily that the explanation must have been that the coins of Domitian's reign, due to their higher intrinsic value, dropped out of circulation faster than those of Vespasian's, according to Gresham's Law (cf. Carradice 1983:5860 and 68-70).

This, however, was a rather slow process. As shown by Table $5 d$, with the 64-98 contents of nine hoards from the territory of the
Roman Empire deposited before AD 170, i.e. Castagnaro (Rizzoli 1914) from northern Italy, Erla (Jungwirth 1967) from Austria, Londonthorpe (Carson et. al. 1979) from Britain, Salasuri (Molnar \& Winkler 1965; Carradice 1977) from Rumania, Osiek (Wruck 1937) and Sotin (Brunsmid 1909) from Yugoslavia, Mocsolad (Gohl 1905) and Kurd-Gyulaj (Mérey 1938) from Hungary and Stockstadt (FMRD I, no. 6020) from the FRG, the proportions were much more to the advantage of Domitian as late as the 160s than in the third century; see for example Stockstadt. It should be added that the coins of Domitian in these hoards are not evenly distributed over his reign; the $98 \%$ fine coins of AD 82-85 disappeared at an early date, leaving those of the period 81-82 ( $89 \%$ fine, the standard of his predecessor Vespasian), and those of the period 85-96 (94\% fine, the standard of Nero; cf. Walker 1976).

Hence, if the coins of the 64-98 period from hoards in Sweden had been brought to the country before $c$. 170 , the portion attributable to the reign of Domitian (81-96) should have been larger, compared to that of Vespasian (69-79) than actually is the case, unless it can be proven that Gresham's Law was operative in Sweden too. In my opinion this is highly unlikely, at least in the case of the pre98 coins: they can never have been available in these parts of Europe in quantities large enough for this to happen. The rareness of the coins of the period 81-96 in Sweden and northern Europe is thus further proof that the large Gotlandic and continental European hoards which are discussed here were exported en bloc from the Imperium Romanum; and this could not have taken place before the third century.

To sum up; as regards the influx of the denarii to Sweden and Gotland, we get this general picture: during the third century denarii were exported in huge quantities from the Roman Empire to what is now Poland (and, I think, to the former Soviet Union too) and from there onwards to Gotland and perhaps the rest of Sweden as well. The point of 
departure on the Continent for specimens arriving on Gotland must have been the region surrounding the mouth of the Vistula River; a route of approach over present-day Germany and/or Denmark is possible for the coins in the rest of the country.
As regards the reasons for this large export of Roman denarii in the third century (or later?), we can only speculate (cf. Lind 1988:205-208).

\section{English revised by Laura Wrang.}

\section{REFERENCES}

Biro-Sey, K. 1987. A keceli éremlelet, Cumania 9. pp. 27-71.

Bolin, S. 1926. Fynden av romerska mynt i det fria Germanien. Studier i romersk och äldre germansk historia. Lund.

Brunsmid, J. 1909. Nekoliko nasasca novaca na skupu u Hrvatskoj i Slavoniji, Viesnik Hrvatskoga Arheologskog Drustva 10(1908-1909) (printed 1909), pp. 241-277.

Carradice, I. A. 1977. The Domitianic Denarii in the Salasuri Hoard, Coin Hoards 3, pp. 70-72.

- 1983. Coinage and Finances in the Reign of Domitian A.D. 81-96. Oxford. (BAR International Series 178).

Carson, R. A. G. et. al. 1979. Recent Coin Hoards from Roman Britain, London (British Museum Occasional Paper 5), pp. 9-24.

Gohl, Ö. 1905. A mocsoladi éremlelet, Numizmatikai közlöny 4, pp. 75-79.

FMRD = Die Fundmïnzen der römischen Zeit in Deutschland. Römisch-Germanische Kommission des Deutschen Archäologischen Instituts zu Frankfurt a. M., hrsg. von H. Gebhart, K. Kraft und M- R.Alföldi, Berlin 1960-

Hildebrand, H. 1866. Svenska folket under hednatiden. Stockholm.

Jungwirth, H. 1967. Der Münzschatzfund von Erla, Numismatische Zeitschrift 82, pp. 26-48.

Kellner, H. J. \& Specht. W. 1961 . Feingehalt und Gewicht des römischen Denars. Bemerkungen zu Sture Bolin, State and Currency in the Roman Empire to 300 A.D., Jahrbuch firr Numismatik und Geldgeschichte 11.

Kunisz, A. 1985.Znaleziskamonet rzymskich z Malopolski. Wroclaw 1985. (Polskie lowarzystwo archeologiczne i numizmatyczne. Biblioteka archeologiczna, 30).

Lind, L. 1979. Roman Denarii Found in Sweden. 2. Catalogue. Text. Stockholm (Stockholm Studies in Classical Archaeology, 11:2).

- 1988. Romerska denarerfuma i Sverige. Stockholm.

- 1991. Was Northern Europe an India to the Ancient Romans? in A. K. Jha (ed.), Coinage, Trade \& Economy, 3rd International Colloquiam, January 8th-11th, 1991, Anjaneri 1991, pp. 168-177.
- (forthcoming): Roman Denarii Found in Sweden. I. Analysis. Stockholm (Stockholm Studies in Classical Archaeology, 11:1).

Mérey, A. 1938. Kurd-gyulaji romai éremlelet, Numizmatikai közlöny 34-35 (1935-1936) (printed 1938), pp. $77 \mathrm{f}$.

Mihailescu-Birliba, V. 1980. La monnaie romaine chez les Daces orientaux. Bucharest. (Bibliotheca Historica Romaniae. Monographies, 23).

Mitkowa-Szubert, K. 1989. The Nietulisko Male Hoards of Roman Denarii. Warsaw.

Molnar, I. \& I. Winkler 1965. Tezaurul de monede romane de la Salasuri, Acta Musei Napocensis 2, pp. 269-294.

Mommsen, Th. 1860. Geschichte des römischen Mïnzwesens. Berlin.

Mouchmov, N. A. 1934. Le Trésor Numismatique de Réka-Devnia (Marcianopolis), Sofia (Annuaire du Musée National Bulgare, 5. Supplement; Éditions du Musée Nationale Bulgare, 31 ).

Pflaum. H.-G. \& H. Huvelin 1981. Le trésor de ViuzFaverges. Trésors monétaire 3, pp. 33-76.

Regling, K. 1912. Römischer Denarfund von Fröndenberg, Zeitschrift für Numismatik 29, pp. 189-253.

$R I C=$ The Roman Imperial Coinage, ed. by H. Matlingly, E. A. Sydenham. C. H. V. Sutherland-, London. 1923-.

Rizzoli, L. 1914. Castagnaro (Verona) tesoretto monetale rinvenuto in predio del Sig. Luigi Fiocco a Mena, Rivista italiana di numismatica 27, pp. 349-364.

Walker, D. R. 1976. The Metrology of the Roman Silver Coinage 1, From Augustus to Domitian. Oxford. (BAR Supplementary Series, 5.)

Wruck, W. 1937. Der Denarfund von Osick (Mursa), Deutsche Münzläter 57, pp. 289-293.

This is an abridged version of my: paper "Was Northern Europe an India to the Ancient Romans?" in A. K. Jha (ed.), Coinage. Trade \& Economy, 3rd Imernational Colloquium, January 8th-11th, 1991, Anjaneri 1991. pp. $168-177$. 
Table 1

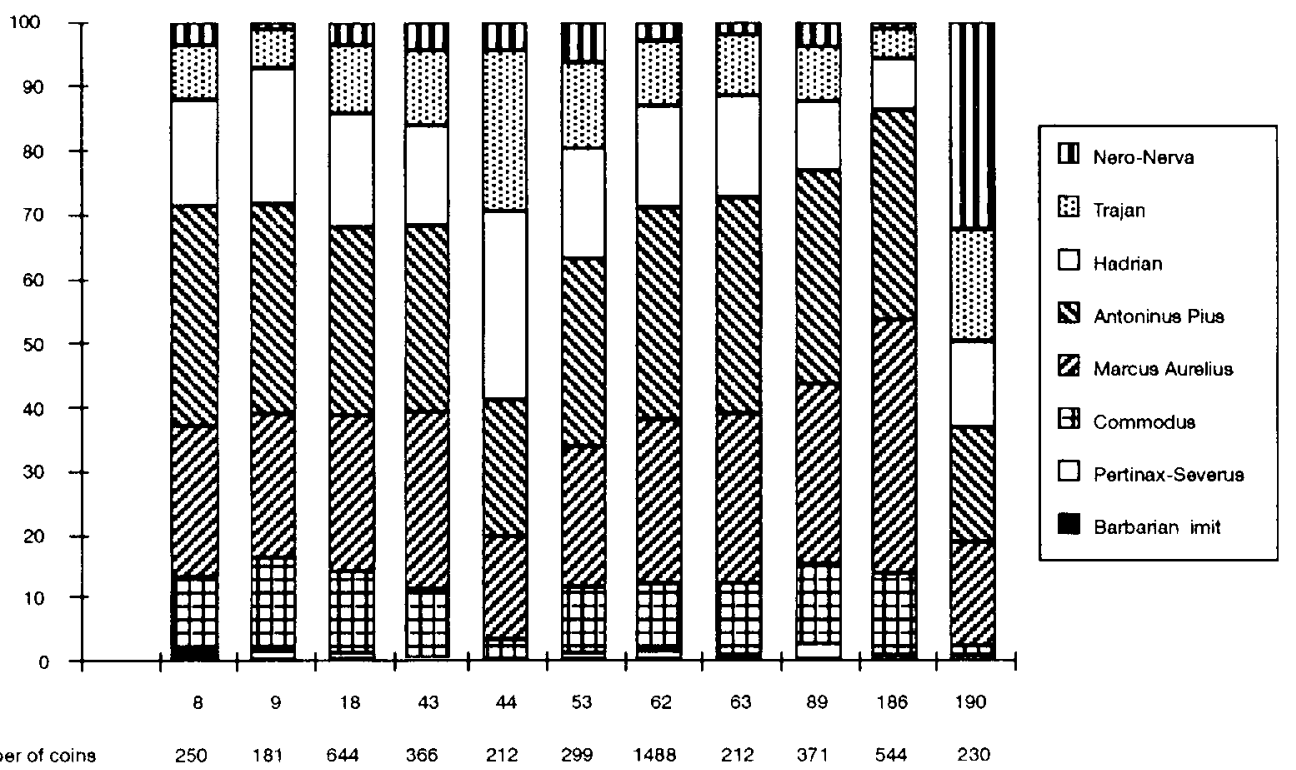

$\begin{array}{llllllllllll}\text { Number of coing } & 250 & 181 & 644 & 366 & 212 & 299 & 1488 & 212 & 371 & 544 & 230\end{array}$

Table 1. Composition of hoards from Golland and the Swedish mainland (emperors' reigns, per cent).

Table 2
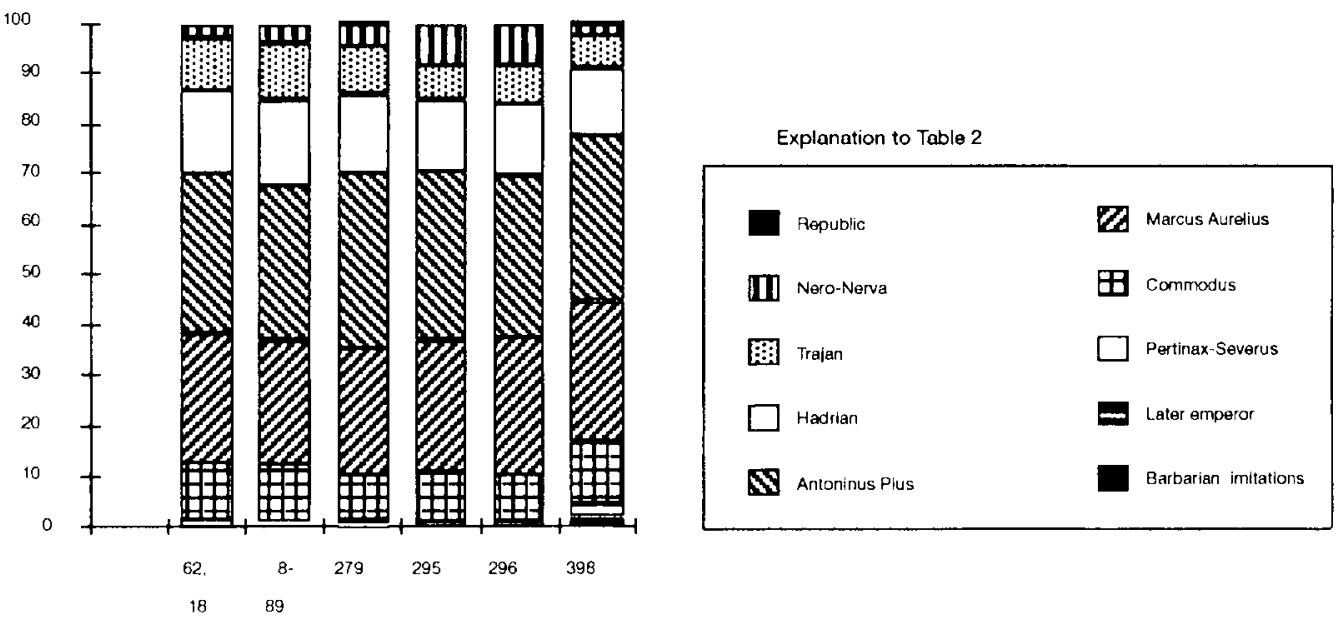

Number of cains $\quad 2132 \quad 1891 \quad 1263 \quad 3170 \quad 1381 \quad 2596$

Table 2. Composition of Gotlandic and Continental hoards (enperors' reigns. per cent). 
Table 3
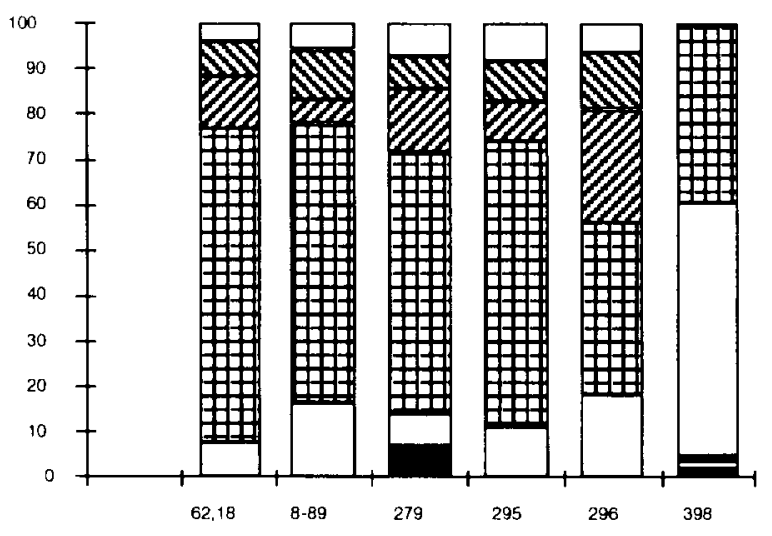

Explanation to Table 3

$\begin{array}{ll}\square \text { Pertinax } & \square \text { Septimius Sever } \\ \mathbf{\Delta} \text { Didius Julianus } & \square \text { Caracalla } \\ \square \text { Clodius Albinus } & \square \text { Macrinus } \\ \mathbf{⿴ 囗 十 ~ S e p t i m i u s ~ S e v e r u s ~ 1 ~} & \end{array}$

Number of coins

26

14

35

$16 \quad 79$

Table 3. Post-192 coins in Gotlandic and Continental hoards (emperors' reigns, per cent).

Table 4

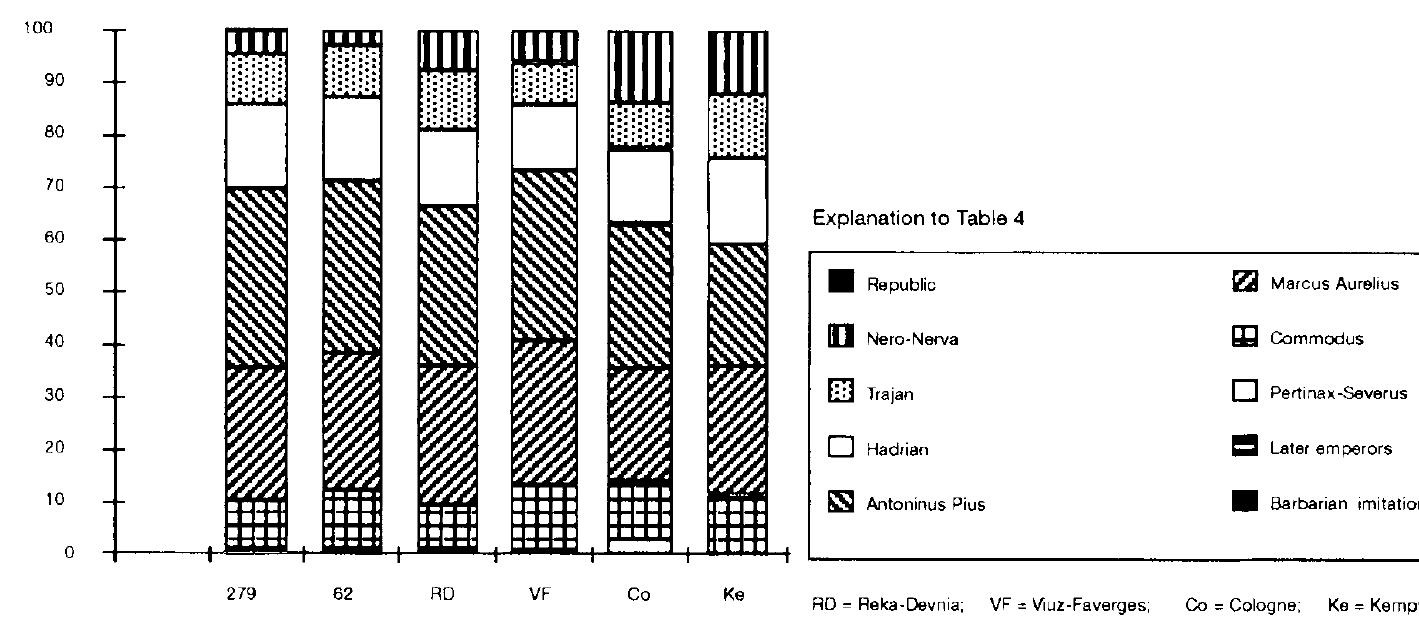

$\begin{array}{lllllll}\text { Number of coins } & 1264 & 1488 & 45485 & 802 & 1380 & 465\end{array}$

Table 4. Composition of nos. 279 and 62 and four Imperial hoards (emperors reigns, per cent). 
Table 5a

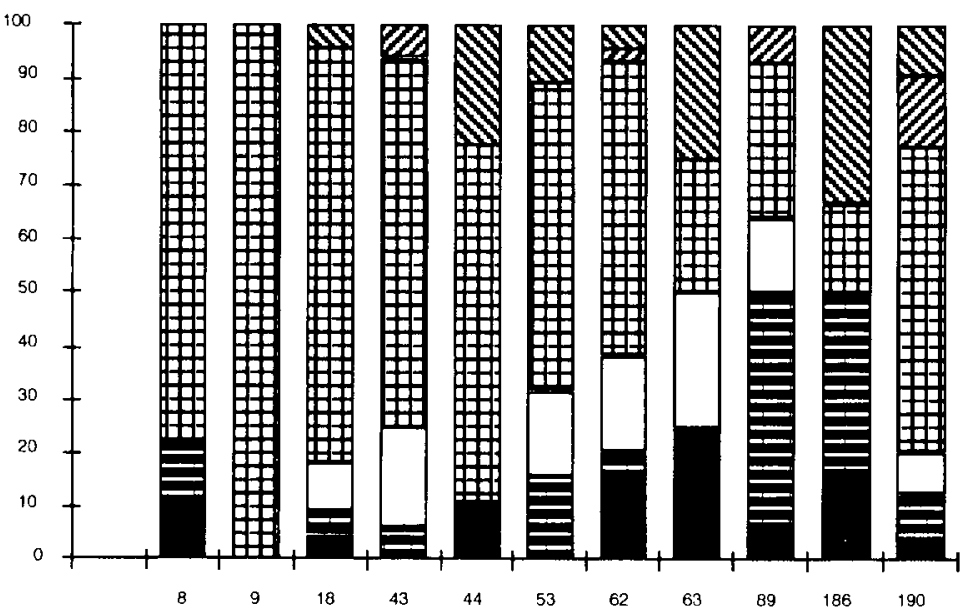

$\begin{array}{llllllllllll}\text { Number of coins } & 9 & 2 & 22 & 16 & 9 & 19 & 44 & 4 & 14 & 6 & 74\end{array}$

Table 5a. Distribution of coins from Nero to Nerva (per cent). Hoards from Gotland and the Swedish mainland.

Explanation to Tables 5a-5d

Table 5b

\begin{tabular}{|ll|}
\hline $\mathbf{W}_{\text {Nero }}$ & $\square$ Titus \\
$\boldsymbol{B}_{\text {Vespasian }}$ & $\square$ Domitian \\
\hline
\end{tabular}

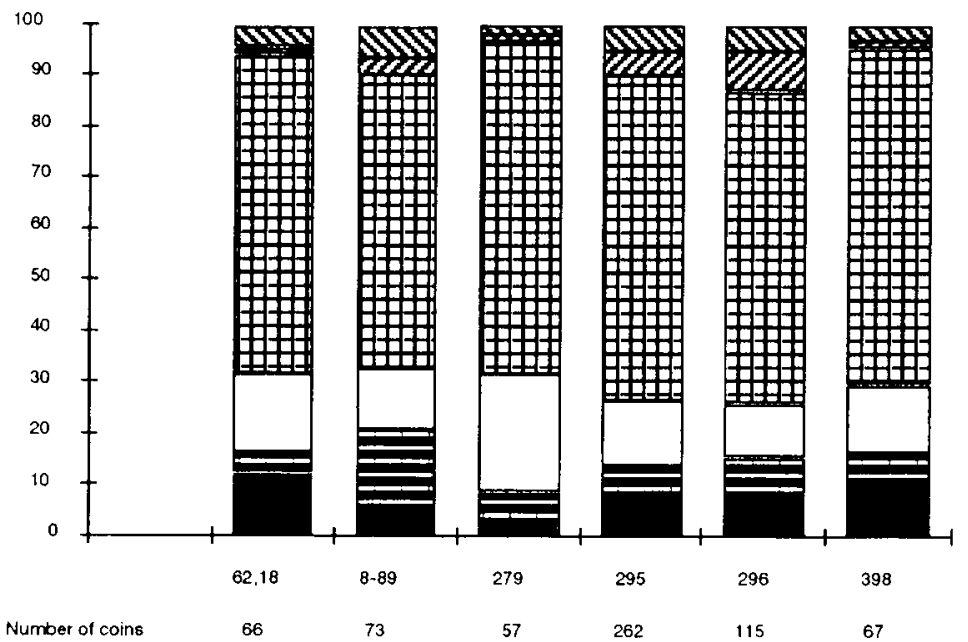

Table $\dot{5}$ b. Distribution of coins from Nero to Nerva (per cent). Gotlandic and Continental hoards. 
Table 5c

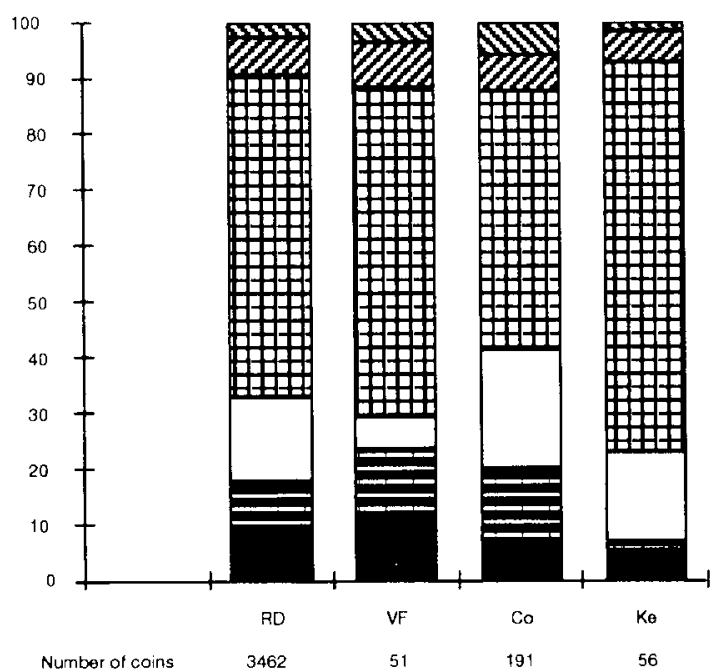

Table 5c: Distribution of coins from Nero to Nerva (per cent). Imperial hoards of 3 rd centary.

\begin{tabular}{|ll|}
\hline $\mathbf{Q}_{\text {Nero }}$ & $\square$ Titus \\
$\Xi_{\text {Vespasian }}$ & $\square_{\text {Domitian }}^{\text {Nerva }}$ \\
\hline
\end{tabular}

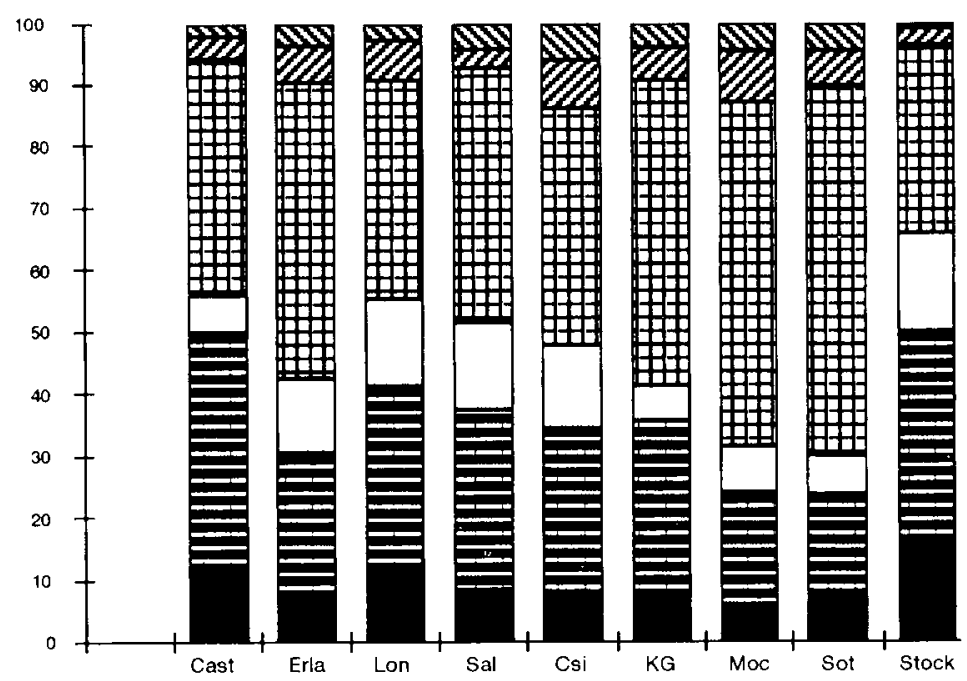

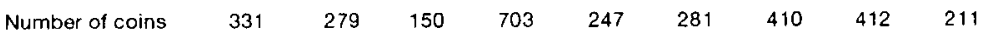

Table 5 d. Distribution of coins from Nero to Nerva (per cent). Imperial hoards of 2 nd centary. 